\title{
Correlation of Neurological Deficits in Patients with Myelomeningocele on the Basis of Anatomical Location and Size of Base of Defect
}

\author{
Muhammad Kashif Bashir*, Aisha Ishtiaq, Aisha Javeed \\ Department of Pediatric Surgery, Mayo Hospital/ King Edward Medical University Lahore, Pakistan.
}

\begin{abstract}
Aims and Objectives: To analyze data regarding relationship of myelomeningocele at different anatomical locations along vertebral canal and size of base defect.
\end{abstract}

Study Design: Descriptive analytic study.

Setting: Department of pediatric surgery, King Edward Medical University / Mayo Hospital Lahore.

Duration of the study: 2 years from October 2017 to September 2018.

Methodology: During study period a total of 60 patients $(n=60)$ with myelomeningocele at different anatomical locations along the vertebral column were admitted. Inclusion criteria was:

- All patients under 3 months of age with myelomeningocele.

- Patients with intact myelomeningocele membrane.

- None infected cases.

A detailed research performa was made having all variables and data was collected regarding total number of patients, gender, location of myelomeningocele along vertebral canal, presence or absence of neural tissue in sac, size of base of defect, associated neurological deficits, treatment and outcome were noted and statistical analysis was done by using SPSS version 24.

Results: A total of 60 patients with myelomeningocele meeting the inclusion criteria were admitted. Most common age of presentation was 1 to 2 month $26(43.3 \%)$. There were $43(71.6 \%)$ males and $17(28.3 \%)$ female patients. Regarding anatomical locations of myelomeningocele along vertebral canal, there were $4(6.6 \%)$ cases of cervical, $2(3.3 \%)$ cases with thoracic, $5(8.3 \%)$ cases with thoracolumber, $38(63.3 \%)$ cases with lumbosacral and $11(18.3 \%)$ cases with sacral myelomeningocel. No neural tissue was found in cervical and thoracic myelomeningocele, but was found in $3(60 \%)$ cases of thoracic lumber myelomeningocele, in 37 (97\%) cases of lumbosacral myelomeningocele, in 11 (100\%) cases of sacral myelomeningocele. No neurological deficit was found in cervical, thoracic and thoraco lumber myelomeningocele. Paralysis of lower limbs was found in $8(13.3 \%)$ cases of lumbosacral myelomeningocele and in $2(3.3 \%)$ cases of sacral myelomeningocele. Paresis of lower limbs was found in $7(11.6 \%)$ cases of lumbosacral myelomeningocele and in $2(3.3 \%)$ cases of sacral myelomeningocele. Fecal incontinence as found in $12(20 \%)$ cases of lumbosacral myelomeningocele and in $4(6.6 \%)$ cases of sacral myelomeningocele. Urinary incontinence was found in $12(20 \%)$ cases of lumbosacral myelomeningocele and in $4(6.6 \%)$ cases of sacral myelomeningocele. In most of cases wound closure was done by simple skin closure, in $12(20 \%)$ cases defect was closed by raising S- shaped rotational flap. Wound infection was noted in $4(6.6 \%)$ cases while there was complete wound dehiscence in $3(5 \%)$ cases. In $2(3.3 \%)$ cases there was post operative leakage of CSF from wound and post operative ventriculitis was observed in 01 (1.6\%) case. Hydrocephalus observed in 16 (26.6\%) cases of myelomeningocele was treated with ventriculo _ peritoneal shunting.

Conclusion: Myelomeningocele is very serious congenital anomaly leading to future disability in children. It can be prevented by prescribing folic acid in pregnancy. A detailed neurological evaluation of patient before and after surgery is important in planning for surgery and rehabilitation.

Keywords: Myelomeningocele, Neural tissue, Neurological deficits, Size of base, Anatomical location, Incontinence, Hydrocephalus.

\section{INTRODUCTION}

Myelomeningocele is the most common neural tube defect affecting over 300,000 births globally each year [1]. The incidence of myelomeningocele is $3-5$ per 1000 live births [2, 3]. A neural tube defect is an opening in the spinal cord or

*Address correspondence to this author at the Department of Pediatric Surgery, Mayo Hospital/ King Edward Medical University Lahore, Pakistan. E-mail: kashif.paeds.surgeon@gmail.com brain that occurs very early in human development [4-6]. Fredrick Ruysch, a Dutch Surgeon, conducted the first extensive case studies on myelomeningocele in 1691 [7]. Folic acid (vitamin B9) and vitamin B12 deficiency in period of orgenogenesis is a very important cause of myelomeningocele [8-11]. Studies showed that this folic acid deficiency and many other potential causes result in malformation of neural tube resulting in congenital neurological deficits [12-15]. Due 
to improved antenatal diagnosis and termination of pregnancy, the incidence of this congenital anomaly is gradually falling in the developed countries. [16,17].

\section{MATERIALS AND METHODS}

All patients were admitted in nursery and nursing care was done in prone position. Injectable 3rd generation cephalosporin was given as prophylactive antibiotic. Wound dressing was done with sofra tulle dressing. After initial resuscitation patients were examined for neurological deficits and any other associated congenital anomaly. Cranial ultrasound was done to check associated hydrocephalus and cortical thickness. On the basis of this cortical thickness we decided to place ventriculoperitoneal shunting before or after surgery. Fecal and urinary incontinence was checked on history and physical examination. Continues fecal soiling and loss of anal tone was seen in fecal incontinent patients while palpable urinary bladder and continues urine dribbling was noted in urinary incontinent patients. Size of base of myelomeningocele at different anatomical locations was measured in circumference and in horizontal directions in centimeters with help of a scale and was noted on prescribed proforma.

\section{RESULTS}

A total of 60 patients with myelomeningocele meeting the inclusion criteria were admitted in Department of Pediatric Surgery King Edward Medical University / Mayo Hospital Lahore. 7 (11.6\%) patients were in age range of 2 to 15 days, $15(25.0 \%)$ patients were in age range of 16 days to 1 month, and $26(43.3 \%)$ patients were in age range of 1 to 2 month and $12(20.0 \%)$ patients in age range of 2 to 3 months (Fig. 1). There were $43(71.6 \%)$ males and $17(28.3 \%)$ female patients with male to female predominance. (Fig. 2).

In distribution of different anatomical locations of myelomeningocele along vertebral canal, there were 4 (6.6\%) cases of cervical myelomeningocele, $2(3.3 \%)$ cases with thoracic myelomeningocele, $5(8.3 \%)$ cases with thoracolumber myelomeningocele, $38(63.3 \%)$ cases with lumbosacral myelomeningocele and $11(18.3 \%)$ cases with sacral myelomeningocel (Fig. 3). Average size of base of defect both in horizontal and circumferential directions was 2.5-3.5 $\mathrm{x}$ $1.5-2.5 \mathrm{~cm}$ in cervical myelomeningocele, $4-5.5 \times 2.5-3.8 \mathrm{~cm}$ in thoracic myelomeningocele , $6-8.5 \times 3.5-7 \mathrm{~cm}$ in thoracolumber myelomeningocele, $10.5-12 \times 5.5-9 \mathrm{~cm}$ in lumbosacral myelomeningocele and 13.5-15 x 7.5-8.5 cm in sacral myelomeningocele. In comparison of anatomical location of myelomeningocele with presence of neural tissue, no neural tissue was found in cervical and thoracic myelomeningocele, but neural tissue was found in $3(60 \%)$ cases of thoracic lumber myelomeningocele, in 37 (97\%) cases of lumbosacral myelomeningocele, in $11(100 \%)$ cases of sacral myelomeningocele (Fig. 4). Measurement of size of base of myelomeningocele done both in vertical and horizontal directions and noted on prescribed proforma (Fig. 5). No neurological deficit was found in cervical, thoracic and thoraco lumber myelomeningocele. Paralysis of lower limbs was found in $8(13.3 \%)$ cases of lumbosacral myelomeningocele and in $2(3.3 \%)$ cases of sacral myelomeningocele. Paresis of lower limbs was found in $7(11.6 \%)$ cases of lumbosacral myelomeningocele and in $2(3.3 \%)$ cases of sacral myelomeningocele. Fecal incontinence was found in $12(20 \%)$ cases of lumbosacral myelomeningocele and in $4(6.6 \%)$ cases of sacral myelomeningocele. Urinary incontinence was found in $12(20 \%)$ cases of lumbosacral myelomeningocele and in $4(6.6 \%)$ cases of sacral myelomeningocele (Table 1). In 48 (80\%) cases defect of myelomeningocele was repaired by simple skin closure, in $12(20 \%)$ cases defect was closed by raising S- shaped rotational flap. Wound infection was noted in $4(6.6 \%)$ cases while there was complete wound dehiscence in $3(5 \%)$ cases. In $2(3.3 \%)$ cases there was post operative leakage of CSF from wound and post operative ventriculitis was observed in $01(1.6 \%)$ case. Hydrocephalus observed in 16 (26.6\%) cases of myelomeningocele was treated with ventriculo _ peritoneal shunting. Telepes equinovarus (due to neurological deficit) noted in $4(6.6 \%)$ cases was treated with application of plaster of Paris with partial improvement. High variety of imperforate anus in $1(1.6 \%)$ case was treated by diverting colostomy. Ectopia vesicae noted in $1(1.6 \%)$ case was treated with definite procedure.

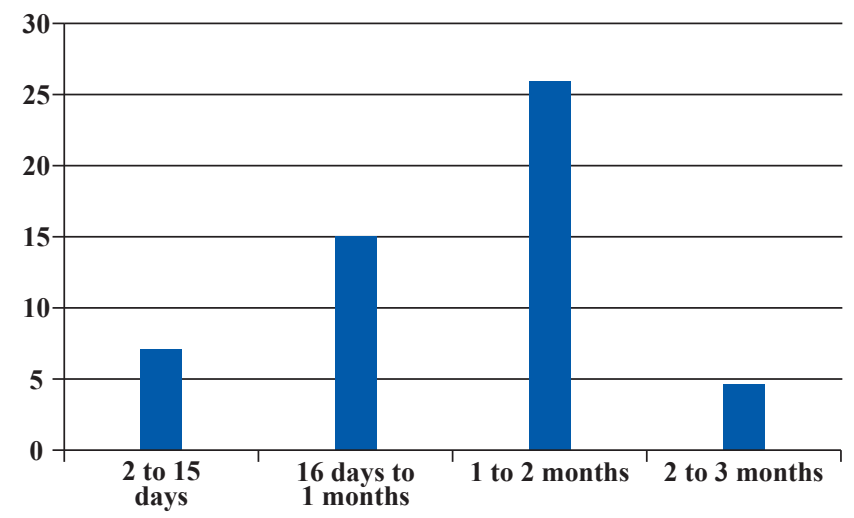

Fig. (1). Distribution of Patients by Age. $(n=60)$

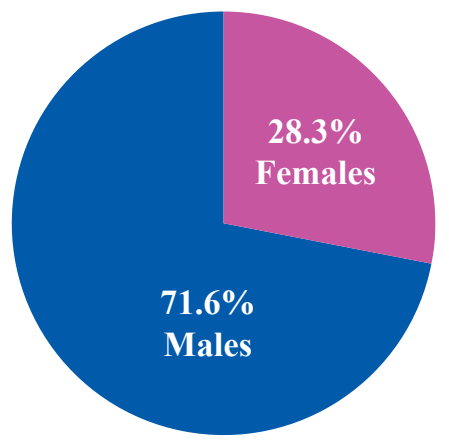

Fig. (2). Distribution of Patients by Gender. 


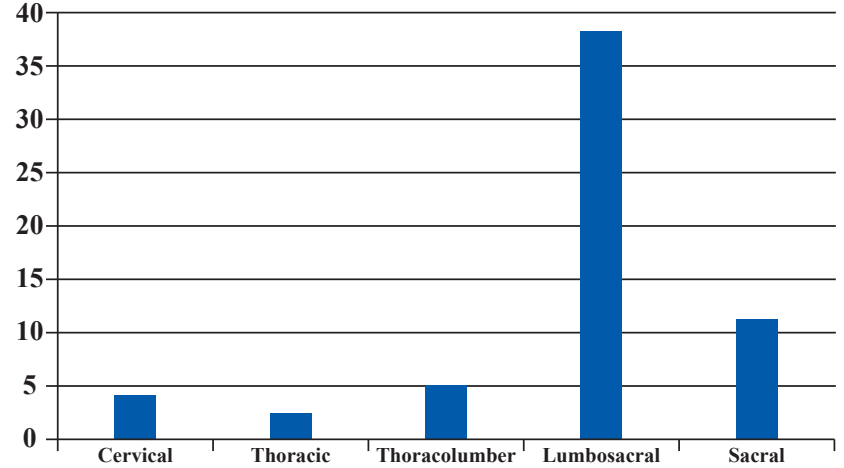

Fig. (3). Distribution of Patients on the Basis of Anatomical Location of Myelomeningocele.

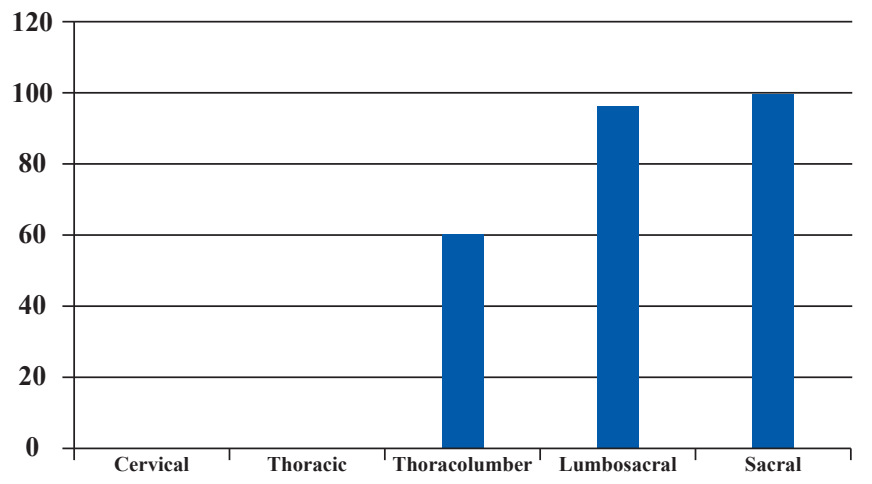

Fig. (4). Relationship between Anatomical Location of Myelomeningocele and Presence of Neural Tissue.

Table 1. Comparison of Size of Base, Presence of Neural Tissue and Neurological Deficit.

\begin{tabular}{|l|c|c|c|c|c|}
\hline \multirow{2}{*}{$\begin{array}{c}\text { Anatomical } \\
\text { location }\end{array}$} & $\begin{array}{c}\text { Average } \\
\text { Size of base }\end{array}$ & \multicolumn{4}{|c|}{$\begin{array}{c}\text { Neurological } \\
\text { deficit }\end{array}$} \\
\cline { 3 - 6 } & & $\begin{array}{c}\text { Paralysis } \\
\text { of lower } \\
\text { limbs }\end{array}$ & $\begin{array}{c}\text { Paresis } \\
\text { of lower } \\
\text { limbs }\end{array}$ & $\begin{array}{c}\text { Fecal } \\
\text { incontinence }\end{array}$ & $\begin{array}{c}\text { Urinary } \\
\text { incontinence }\end{array}$ \\
\hline Cervical & $2.5-3.5 \times 1.5-2.5$ & 0 & 0 & 0 & 0 \\
\hline Thoracic & $4-5.5 \times 2.5-3.8$ & 0 & 0 & 0 & 0 \\
\hline Thoraco lumber & $6-7.5 \times 3.5-7$ & 0 & 0 & 0 & 0 \\
\hline Lumbo sacral & $10.5-12 \times 5.5-9$ & 8 & 7 & 12 & 12 \\
\hline Sacral & $13.5-15 \times 7.5-8.5$ & 2 & 2 & 4 & 4 \\
\hline
\end{tabular}

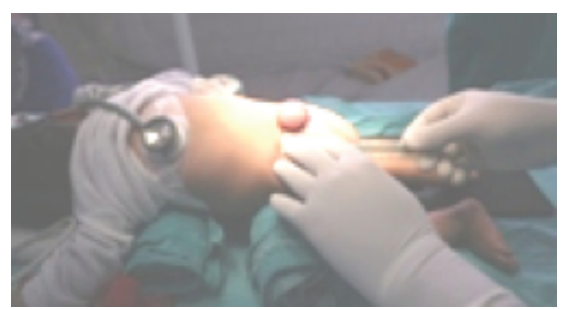

Fig. (5). Measurement of Myelomeningocele with Scale in Vertical and Horizontal direction.

\section{DISCUSSION}

All patients included in this study were operated and followed up in Outpatient department after discharge. When the data was analyzed, it was seen that myelomeningocele is more common in males as compared with females. Similar results were also seen in other national and international studies [18]. In our study lumbosacral spine is the most common anatomical site for myelomeningocele $(63.3 \%)$ which is consistent with the other studies [19]. When anatomical location of myelomeningocele was compared with presence of neural tissue in myelomeningocele sac, it was noted that incidence of neural tissue presence increases from cervical to sacral spine along the vertebral canal because no neural tissue was found in cervical myelomeningocele and maximum neural tissue was found in sacral myelomeningocele. These findings are comparable with other studies [20-22]. In our study it was also noted that incidence of associated congenital anomalies and neurological deficit also increases from cervical to sacral spine as maximum neurological deficit was noted in thoraco-lumber and sacral myelomeningocles. Similar results were also noted in other studies which showed maximum presence of neural tissue in lumbosacral and sacral myelomeningoceles leading to more neurological deficits [23]. when size of base of defect was compared with anatomical location along the vertebral canal it was noted that size of base of defect increases from cervical to sacral spine, and when this size was compared with associated neurological deficits it was found that as the size of base defect increases, chance of associated neurological deficits also increases, as maximum neurological deficits were noted in lumbosacral and sacral myelomeningoceles. These results are comparable with other studies which showed similar results [24]. In our study hydrocephalus was treated with ventriculopertoneal shunting in $14(23.3 \%)$ patients before myelomeningocele repair and in $2(3.3 \%)$ patients after myelomeningocele surgery. These findings are comparable with another international study which showed that $63 \%$ of the children with hydrocephalus required shunt surgery prior to the definitive surgery [25]. According to our study most of cases $(80 \%)$ of myelomeningocele can be closed by simple skin closure but in cases of vide base defect, wound closure can be done by raising S- shaped flaps. Other studies also showed that rotational skin flaps are more suitable in case of under tension skin closure. In our study the paralysis of lower limbs was noted in 10 cases $(16.6 \%)$ which is less than $60 \%$ reported by Campbell KS and it is comparable to the findings of Volpe $\mathrm{J}$, et al. where the partial paralysis was in $21.72 \%$ cases [26].

\section{CONCLUSION}

Myelomeningocele is an obvious congenital malformation and complications associated with it are so noticeable that the condition must have been known since the earliest days of history. Pre operative and surgical management depends on many factors. Before planning surgery patients should be 
evaluated for defect size and site. Any source of infection and leakage of CSF should be ruled out before and after surgery. Surgery should be aimed to prevent further neurological deficits and efforts should be made to prevent complications of this congenital anomaly to improve quality of life.

\section{CONFLICT OF INTEREST}

Declared none.

\section{ACKNOWLEDGEMENTS}

Declared none.

\section{REFERENCES}

[1] Bowman RM, Boshnjaku V, McLone DG. The changing incidence of myelomeningocele and its impact on pediatric neurosurgery: A review from the Children's Memorial Hospital. Childs Nerv Syst 2009; 25: 801-6.

DOI: $10.1007 / \mathrm{s} 00381-009-0865-\mathrm{Z}$

[2] Bruner JP, Tulipan N, Paschall RL, et al. Fetal surgery for myelomeningocele and the incidence of shunt-dependent hydrocephalus. JAMA 1999; 282(19): 1819-25.

DOI: $10.1001 /$ jama.282.19.1819

[3] Badhiwala JH, Nassiri F, Kulkarni AV. Open neural tube defects. In: Di Rocco C, Pang D, Rutka JT, Eds. Textbook of Pediatric Neurosurgery. Switzerland: Springer International Publishing 2019; pp. 1-29.

DOI: 10.1007/978-3-319-31512-6_108-1

[4] MacKenzie TC, Adzick NS. Prenatal diagnosis of congenital malformations. Pediatric Surgery. Switzerland: Springer International Publishing 2019; pp. 1-15.

DOI: 10.1007/978-3-642-38482-0_3-3

[5] Maroto A, Illescas T, Meléndez M, et al. Ultrasound functional evaluation of fetuses with myelomeningocele: Study of the interpretation of results. J Matern Fetal Neonatal Med 2017; 30(19): 2301-5. DOI: 10.1080/14767058.2016.1247262

[6] Kermorvant-Duchemin E, Ville Y. Prenatal diagnosis of congenital malformations for the better and for the worse. $\mathrm{J}$ Matern Fetal Neonatal Med 2017; 30(12): 1402-6.

DOI: $10.1080 / 14767058.2016 .1214707$

[7] Domröse CM, Bremer S, Buczek C, et al. Termination of pregnancy after prenatal diagnosis of spina bifida: A German perspective. Arch Gynecol Obstet 2016; 294(4): 731-7. DOI: $10.1007 / \mathrm{s} 00404-016-4032-y$

[8] Felkner M, Suarez L, Canfield MA, et al. Maternal serum homocysteine and risk for neural tube defects in a Texas-Mexico border population. J Clin Mol Teratol 2009; 85(6): 574-81. DOI: $10.1002 /$ bdra.20545

[9] Imbard A, Benoist JF, Blom HJ. Neural tube defects, folic acid and methylation. Int J Environ Res Public Health 2013; 10(9): 4352-89. DOI: $10.3390 /$ ijerph10094352
[10] Wang X, Wang J, Guan T, et al. Role of methotrexate exposure in apoptosis and proliferation during early neurulation. J Appl Toxicol 2013; 18: 915-23.

[11] Zhao J, Guan T, Wang J, et al. Influence of the antifolate drug Methotrexate on the development of murine neural tube defects and genomic instability. J Appl Toxicol 2013; 33: 187-91. DOI: $10.1002 /$ jat.2769

[12] Sukanya S, Bay BH, Wah Tay SSW, et al. Frontiers in research on maternal diabetes-induced neural tube defects: Past, present and future. World J Diabetes 2012; 3(12): 196-200. DOI: 10.4239/wjd.v3.i12.196

[13] Rasmussen SA, Chu SY, Kim SY, et al. Maternal obesity and risk of neural tube defects: A metaanalysis. J Obstet and Gynecol 2008; 1(4): 170-8. DOI: 10.1016/j.ajog.2008.04.021

[14] Chen FC, Gerhardt J, Entezami M, Chaoui R, Henrich W. Detection of spina bifida by first trimester screening - results of the prospective multicenter Berlin IT-study. Ultraschall Med 2015; 21(4): 51-3. DOI: 10.1055/s-0034-1399483

[15] Lu QB, Wang ZP, Gong R, Sun XH, Gao LJ, Zhao ZT. Investigation of ultrasound screening efficiency for neural tube defects during pregnancy in rural areas of China. J Public Health 2011; 125(9): 639-44.

DOI: 10.1016/j.puhe.2011.06.007

[16] Rodrigues ABD, Krebs VLJ, Matushita H, de Carvalho WB. Short-term prognostic factors in myelomeningocele patients. Child's Nervous System 2016; 32(4): 675-80. DOI: $10.1007 / \mathrm{s} 00381-016-3012-7$

[17] Anglim B, Mandiwanza T, Miletin J, Turner M, Kennelly MM. The natural history of neural tube defects in the setting of an Irish tertiary referral foetal medicine unit. J Obstet Gynaecol 2016; 36(1): 19-23.

DOI: $10.3109 / 01443615.2015 .1030597$

[18] Bixenmann BJ, Kline-Fath BM, Bierbrauer KS, Bansal D. Prenatal and postnatal evaluation for syringomyelia in patients with spinal dysraphism. J Neurosurg Pediatr 2014; 14(3): 316-21. DOI: 10.3171/2014.5.PEDS13482

[19] Lei T, Xie H-N, Zheng J, Feng J-L, Du L, Wang N. Prenatal evaluation of the conus medullaris position in normal fetuses and fetuses with spina bifida occulta using three-dimensional ultrasonography. Prenat Diagn 2014; 34(6): 564-9.

DOI: $10.1002 /$ pd.4349

[20] Donkelaar HJT, Bekker M, Renier WO, Hori A, Shiota K. Neurulation and neural tube defects. In: Donkelaar HJT, Lammens M, Hori A, Eds. Clinical Neuroembryology. Switzerland: Springer 2014; pp. 165-217. DOI: $10.1007 / 978-3-642-54687-7 \_4$

[21] Andrew J Copp, Philip Stanier, Nicholas DE Greene. Neural tube defects: Recent advances, unsolved questions, and 
controversies. Lancet Neurol 2013; 12(8): 799-810.

DOI: 10.1016/S1474-4422(13)70110-8

[22] Kumar R, Singhal N. Outcome of myelomeningocele, lipomeningocele in Children of northern India. J Pediatr Neurosurg 2007; 5(43): 7-14. DOI: 10.1159/000097518

[23] Campbell KS, Vander L, Palisano R. Physical therapy for children. J Phys Therapy 2011; 11(5): 115-22.

[24] Millichap JG. Arnold-Chiari with myelomeningocele. J
Pediatr Neurol Briefs 2016; 1(4): 28-9. DOI: 10.15844/pedneurbriefs-1-4-8

[25] Boulet SL, Yang Q, Mai C, et al. Trends in the postfortification prevalence of spina bifida and anencephaly in the United States. J Birth Defect Res 2008; 82(7): 527-32.

DOI: $10.1002 /$ bdra. 20468

[26] Volpe J. Neural tube formation and procencephalic development. J Neuro Surg 2011; 5(12): 120-7.

Received: January 24, 2020

Revised: April 26, 2020

Accepted: April 28, 2020

(C) 2020 National Journal of Health Sciences.

This is an open-access article. 